\title{
Business Model to the LASSE performance at Microgrid environment
}

\author{
W. Polini ${ }^{2}$, R. C. Lotero ${ }^{2}$, and R. B. Otto ${ }^{1}$ \\ ${ }^{1}$ LASSE - Automation and Electrical Systems Simulation Laboratory \\ Parque Tecnológico Itaipu - Foz do Iguaçu, Paraná (Brazil) \\ Phone/Fax number: +55 (45) 35767089, e-mail: rodrigobueno@pti.org.br \\ ${ }^{2}$ UNIOESTE - Paraná West State University \\ Região Norte, Foz do Iguaçu, Paraná, Brazil
}

Phone/Fax number: +55 (45) 91342679, roberto.lotero@gmail.com ; werike_polini@hotmail.com

\begin{abstract}
The Microgrid (MG) scenario has a socioeconomic and technical character seeking to promote the sustainable, technological and economic advance. Through the MG, the consumer may set up its own business with a the sale of its own energy, thus, the Automation and Electrical Systems Simulation Laboratory (LASSE) is interested in participating of the MG market. Creating and/or innovating a business requires knowledge of the application environment. This reality has as consequence the determination of strategies for the company's management in the vision of the market dynamics. This research aims to define the necessary requirements for the performance of LASSE in the MG environment and to develop the systemic LASSE diagram associating the structural elements of the business model with the characteristics of LASSE. The information was generated through the Business Model Generation (BMG) methodology, among which the Business Model Canvas tools stand out. The research interests LASSE for creating ideological guidelines for members of the LASSE Smart Energy Project. In this way, it is possible to clearly understand the process of introduction to the MG environment, as well as the necessary characteristics for the elaboration of Business Models (BM).
\end{abstract}

\section{Key words}

Smart Grid, Microgrid, Business Model, Systemic Vision

\section{Introduction}

Concerns about the environment, population growth, economic development and the resulting increase in of energy demand are some of the factors that motivate the development of small-scale electric energy technology and based on paradigm shifts from traditional generation centers to renewable sources, shifting the paradigm of large traditional generation centers [1].

Commonly, the technologies are connected to low voltage networks and are called "Distributed Generation" (DG) [2]. With the increase insertion of this type of DG appears the interest by the intelligent MG with the intensive use of information technology, control, automation and communication, making the system more efficient and operate autonomously [3]. Through the MG, even-the consumer can generate and sell its own energy, constituting the so-called "prosumer", increasing the possibility of competition in the energy market [4].

With regard to socio-economic aspects, a great opportunity is opened to create value with companies interested in investing, innovating and generating profits through value propositions. In a complex market such as electricity, there are evidently great uncertainties that can affect the business, and it is necessary to identify them, which can be done by knowing the BM [5].

Even if there is no consensus of a clear definition of BM, it can be said that it is an abstraction of a complex business, which seeks to show the set of interdependent elements that compose it and the interrelationships among these elements, manifested in the causal relationship "choices -consequences", which is a system. The BM, in this systemic view, allows its analysis, understanding, design and development, providing the best management of the organization and allowing to "simulate" or "experiment" behaviour in the development of current and future business [6].

Osterwalder and Pigneur, in 2010, developed the BMG methodology, which is a common language that allows to easily describe and manipulate BM, making possible the creation of new strategies. Without this language, it is difficult to systematically evaluate the assumptions about a BM and innovate successfully [7].

In this context, and considering the opportunity to compose an MG Business Model, it is of interest to the LASSE to expand its form of value capture through the LASSE Smart Energy project. LASSE can be an organization that elaborates a set of activities, such as the forms of business units, that face barriers and unrelated difficulties and no unqualified means are inserted. 
Therefore, it is necessary that the LASSE be able to be characterized in an efficient and effective, having as function the functioning of the system and, thus, as sources of uncertainty and consequently contributing to the success of the business.

Consequently, the objective of the work was to develop a $\mathrm{BM}$ for the performance of LASSE in the Electric Power industry, focusing on the development of MG studies and applications. The BM will allow LASSE to visualize the dynamics of the system that constitutes this type of business, seeking to mitigate the intrinsic uncertainties of the same, considering the complex and changing characteristics of the electricity market.

\section{Business Model}

The business world becomes more and more competitive and, for this reason, organizations are looking for innovations at all times, in order to guarantee their existence. As consumers develop to adapt to this economic system, every conception contained in an enterprise changes to meet their demand. Companies then change what they think about the products, services, processes, technologies and sales forms.

As a result, the BM development has become a common practice among organizations to achieve the goal of understanding the system operation and thus generate sources of uncertainty and consequently reduce risk, contributing to the success of the business [7].

The creation of a BM simplifies a given phenomenon to the entity, helping to understand, describe or predict how the real world works. Thus, in the specific case of a BM of a company, it must understand, describe and predict the activity of buying and selling goods and services and how to make a profit [6].

Therefore, the main bibliographical reference for this work is the BMG, which was originated in Alexander Osterwalder's doctoral thesis, defended at the University of Lausanne, Switzerland in 2005, later updated in 2009 with the help of Yves Pigneur and more of 450 employees around the world.

\section{A. Business Model Canvas}

Canvas is a strategic tool of analysis in the form of a framework, which through this analysis can be perceived as the original idea of the business and if the parts fit into truly forming an integrated system. The use of Canvas is more practical, visual, and allows a constant integration with the entrepreneurs and team who wish to innovate and stand out from the others.

Osterwalder and Pigneur, in 2010, propose a BM covering the three conceptual pillars of its definition, describing nine dimensions that interact and relate, explaining the exchanges between different environments. The pillars of the BM are structured in value creation (key partners, key activities and key resources), value delivery (channels, customer segments and customer relationships), and value capture (revenue streams and cost structure).

What is interesting is that none of the nine elements of Canvas (Tab 1) are considered as new by entrepreneurs, but the representation of the BM in a holistic way and on only one sheet of paper (Fig. 1) is something innovative for most entrepreneurs.

Table I - The nine building blocks.

\begin{tabular}{|l|l|}
\hline \multicolumn{1}{|c|}{ Building Blocks } & \multicolumn{1}{|c|}{ Definition } \\
\hline Customer Segments & $\begin{array}{l}\text { Different groups of people or } \\
\text { organization an enterprise aims to } \\
\text { reach and serve. }\end{array}$ \\
\hline Value Propositions & $\begin{array}{l}\text { Bundle of products and services } \\
\text { that crat value for a specific } \\
\text { customer. }\end{array}$ \\
\hline Channels & $\begin{array}{l}\text { How a company communicates } \\
\text { with and reaches its Customer } \\
\text { Segments to deliver a Value } \\
\text { Proposition. }\end{array}$ \\
\hline Relationship & $\begin{array}{l}\text { Types of relationships company } \\
\text { establish with a specific customer. }\end{array}$ \\
\hline Key Resources & $\begin{array}{l}\text { Cash a company generates from } \\
\text { each customer. }\end{array}$ \\
\hline Key Activities & $\begin{array}{l}\text { Most important assets required to } \\
\text { make a business model work. }\end{array}$ \\
\hline Key Partnerships & $\begin{array}{l}\text { Most important things a company } \\
\text { must do to make its business model } \\
\text { work. }\end{array}$ \\
\hline Cost Structure & $\begin{array}{l}\text { The network of suppliers and } \\
\text { partners that make the business } \\
\text { model work. }\end{array}$ \\
\hline
\end{tabular}

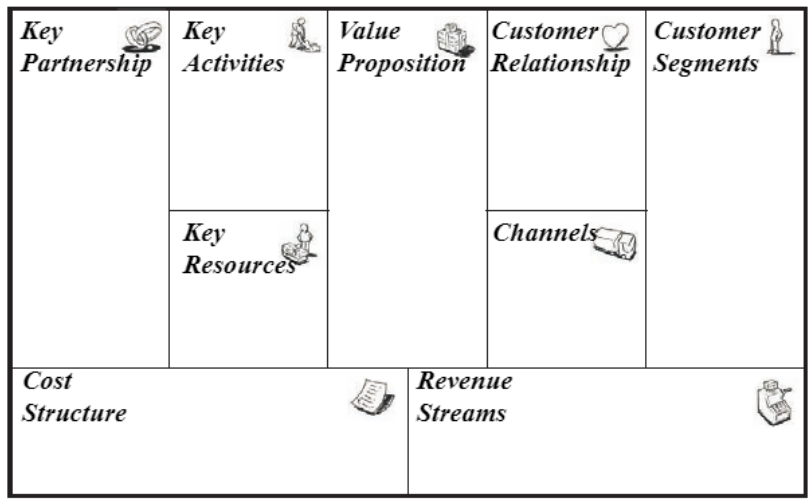

Fig 1. Business Model Canvas.

\section{B. Systemic Vision and Negotiation Process of the Business Model}

From the idea of systems, the word systematization represents the order or classification of different elements, from rules or similar parameters, resulting in a re-elaboration of the thinking by those who are applying it and allowing a new organization for a system. The systematization, therefore, establishes the order of a system that has the objective of obtaining positive results in the mission that is intended to be achieved. In a more technical way, system inputs are anything that comes from outside its boundary, and outputs are what the system releases beyond its boundaries as a result of its operation [8]. It is necessary to understand how systemic 
thinking contributes to the elaboration of an effective and innovative BM, considering its dimensions. Systemic thinking offers a common formal starting point for different views about a complex BM. It allows the inclusion of a complete BM with all components and elements thought holistically (function, structure, process, and control) (Fig.2) and also an interdisciplinary view of different areas, for example, economics, law, management and technology [9].

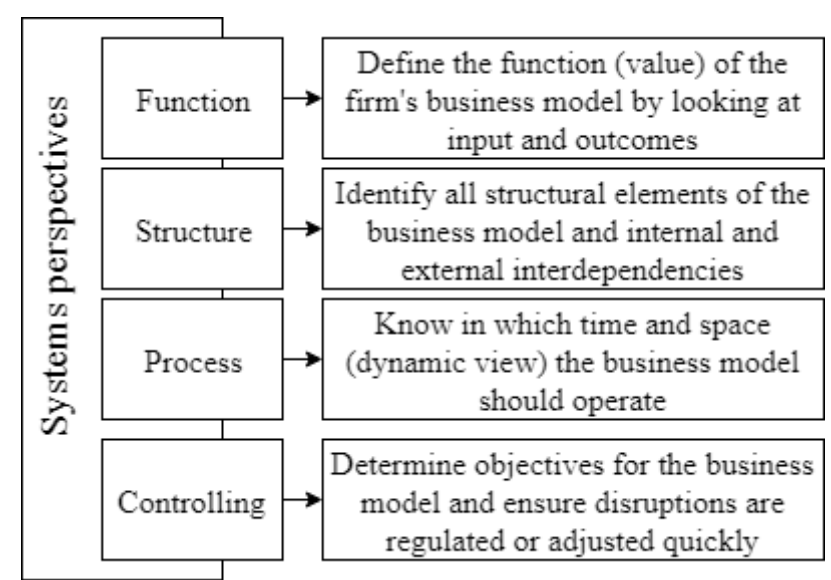

Fig 2. Systems perspectives.

The negotiation process, being one of the categories of the organizational policy, is seen from the strategic direction of the company, but this strategy cannot be thought independently of the other elements of the system. The company must structure its negotiation processes by carrying out analyses that include: the company's positioning in relation to the other market players, the necessary skills to the negotiator, the company's partnerships and competitors, the basic variables involved in the negotiation process to be initiated, level of internal integration between the different areas of the company and the negotiation tools available [10]. From a systemic view and negotiation process, the professional that understands the company in which it operates achieves above-average results. This is because this professional is able to identify his role clearly, and performs his activities effectively and efficiently, acting assertively to achieve the goals set for himself for the BM. With the systemic vision, you have the advantage of being able to adapt better to any situation, an advantage that is also very necessary in the job market.

\section{Identification of LASSE characteristics}

The Automation and Electrical Systems Simulation Laboratory (LASSE) is an organization located in the Itaipu Technological Park (PTI), since 2007, whose mission is to bring a technological update to Itaipu Hydroelectric Power Plant using the real-time simulation platform (RTDS $®)$. For a verification of this session, there were interviews with a team of LASSE technicians and management to identify the main aspects that characterize an institution, both structurally and organizationally.

\section{A. Strategy}

When the first contact with the customer is made, he presents the interests and needs, and the company defines the demand entry. Upon entry of the demand, the team analyses the feasibility of project execution, resulting in the definition of resources and also the accuracy of delivery time. Finally, all this survey is presented to the manager to make management decisions resulting in technical advice. Having a positive technical opinion, all the requirements are used for the elaboration Work Order (WO) and the Work Plan (WP). After that, the technical team prepares technical documents that contain orientation diagrams for developing software, drawings and document architectures of the hardware, important for the continuity of the project. From then on, all the theoretical baggage is applied and the software and/or hardware that make up the desired solution, installed in the field and tested, all accompanied by the customer. Finally, the completion of the project that results in the closing of the WO is carried out. The final report describing the activities, project information and possible Continuous Improvement plans for the product is submitted.

\section{B. Partnerships}

In addition to Itaipu, another important partner, and also responsible for encouraging the creation of LASSE, was the Applied Technological Institute and Innovation (ITAI). This non-profit institution, created in 1996, began to act first with the objective of fomenting the critical mass in the region. Due to the creation of the PTI Foundation (FPTI), responsible for the management of the PTI, ITAI needed to restructure creating several competency cells in the PTI, giving continuity to specific engineering and computation Research and Development $(\mathrm{R} \& \mathrm{D})$ project lines. Within these cells were a group of computer networks, a research group in biomass energy generation and a group of automation and simulation in electrical systems. Due to the advancement of these competence cells, many of them came to behave as autonomous centers. Thus, the competence cell for automation and simulation in electrical systems gave rise to LASSE. Also has partnerships with institutions of higher education and research, such as Paraná West State University (UNIOESTE) itself, the University of São Paulo (USP / São Carlos), the Federal University of Latin American Integration (UNILA), the Federal University of Paraná (UTFP) and the Federal University of Paraná (UFPR).

As the primary supplier, RTDS $®$ offers customized hardware and software capable of conducting electromagnetic transient simulations in real time. Just as the OPAL-RT company offers PC / FPGA (programmable processors) technology, hardware-in-theloop (HIL) test equipment and Rapid Control Prototyping (RCP) systems to design, test and optimize control and protection of electrical systems. It is through this technology that LASSE offers its main value proposition to the electric energy market, which makes it a benchmark in the sector. The other supplier is National Instruments (NI). This company leverages LASSE with products such as market software and modular hardware that are cost-effective, such as LabVIEW, CompactRIO, and PXI. 


\section{Areas Integration}

One of the benefits of doing a project with LASSE is that in addition to having environments for testing and testing, there is also an organizational structure with teams responsible for the technical decisions of the projects, divided into five areas. They are R\&D, Electrical Studies, Automation, Electronics and Automation Technology. In each area, there is a small team responsible for the technical support of the WP. Each area may act both independently and integrated with other existing areas. The advantage of acting independently is that one area does not need the others to make a decision and the advantage of working in an integrated way is that people from the team in a given area can participate in decisions in other areas, qualifying decision-making and providing a more favourable space for sharing ideas.

\section{Trading Tools}

To develop the activities that constitute the value proposition, LASSE has the following tools:

1) RTDS® simulator: composed of 4 racks with the possibility of simulation up to 88 bus;

2) $O P A L-R T ®(O P 4510)$ : carrier FPGA, 16 analog inputs and outputs and 32 static digital inputs and outputs with the possibility of implementation in the Simulink/MATLAB environment;

3) Monitoring Systems: includes the monitoring of transformers, circuit breakers, generating units, conditions in electric machines, partial discharges, lightning rods, battery bank, among others;

4) Embedded system: electronic and customized software for systems developed in own hardware or market;

5) Industrial Panels: assembly of the solutions in panels following the most demanding standards of the industry, considering the standardization of all required technical documentation;

6) $R \& D$ : a set of partnerships seeking solutions for the Brazilian electricity sector.

\section{E. Trading variables and skills}

The technical decisions, as previously mentioned, are made by small teams that work in the following five areas: R\&D, electrical studies, automation, electronics, and automation technology. When these teams define the technical issues of the projects, everything will be passed on to the technical coordinator who will then forward to the manager. The technical coordinator has the function of coordinating the technical teams, giving all the support they need, and the function of executing the WP made by them. Any technical decision of a project made in one or all areas requires the approval of the LASSE manager. This receives the complete information about the projects and makes the final decision. In case of absence from the institution, the technical coordinator represents him. The LASSE manager has a strategy similar to that of the FPTI: to manage the projects, the financial part and the staff of the institution, just as the FPTI does in relation to the PTI. In addition, the LASSE manager is always analyzing the market, considering future business, and also in the condition of standing out in the market to achieve a new project. This organizational structure of LASSE favors the variables of negotiation and competence (time, information and power) established in the systemic view since all the professionals need to work in tune to win the client and also so that the LASSE is recognized in the market.

\section{Smart Grid Business Model in the context of LASSE}

Changes in electricity generation and consumption are transforming the industry's traditionally upstream/downstream a value chain into a more decentralized organization. The structure of the industry value chain has always been vertically integrated around utilities, giving rise to new entrances at different points of value chain, among which are the consumers themselves. Figure 3 positions the Smart Grid business model into three categories. [4]

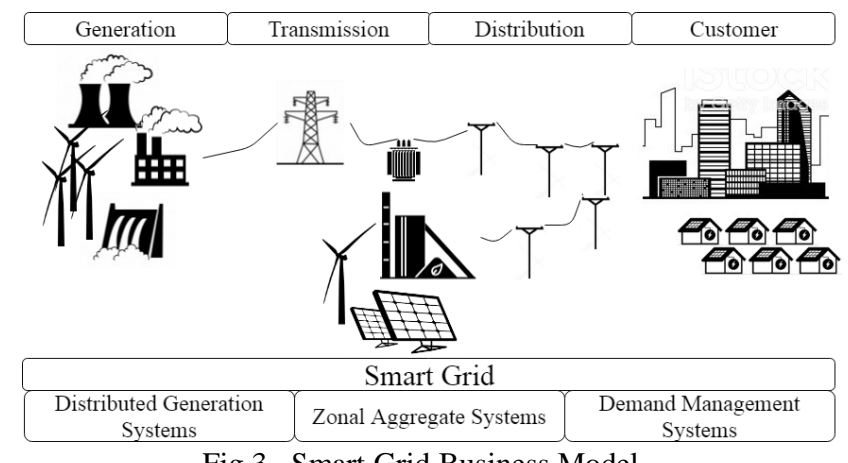

Fig 3. Smart Grid Business Model.

The DG category has two subcategories, called Rent to Space and Power Purchase Agreement. In the Power Purchase Agreement subcategory, the incumbent is responsible for designing, installing, maintaining and operating the DG equipment. In the Rent-to-Space subcategory, the incumbent needs to rent an area to install the micro-grid, as well as design, install, maintain and operate the DG equipment. The main criterion of difference between the two, then, is the need or not to have an area to install the MG In addition, the choice of the subcategory will vary according to the needs of the buyer, the seller and the financing of the counterparts, impacting on the tariffs charged [4].

The Zonal Aggregated Systems category coordinates the transmission and distribution of the DG, integrating these three activities so that the consumer receives the energy in an intelligent way. It has two subcategories called Virtual Power Plant and MG. The subcategory Virtual Power Plant corresponds to the set of DG and Controllable Loads that regulate the production in blocks of energy. The Virtual Power Plant allows the system to react better to fluctuations, but the complexity of the system requires secure control and communication. As for the MG subcategory, this corresponds to the intelligent connection between renewable generation 
sources and the consumer, based on information technology, control, automation, and communication [3].

Finally, the third and last category of the Smart Grid is called Demand Management. In it are ways thought for the consumers about the consumption of electrical energy in order to save it. Energy services are offered by companies via equipment to reduce and optimize consumption, taking into account the installation of systems and equipment (smart meters) with proactive management of energy consumption, that is, the customer can control what he or she spends. The Demand Management category has two subcategories: Smart Home and Demand for Responsibility. The Smart Home subcategory corresponds to the control, automation, and supervision of homes via communication protocols, using sensors in everyday objects such as notebooks, air conditioners, televisions, and refrigerators. The subcategory Demand for Responsibility corresponds to the act of the companies paying for the consumers to reduce the consumption when they like. Thus, they are able to offer the network operators or public services the reduction of demand when these agents need [11].

\section{LASSE Smart Energy Business Model}

The LASSE Smart Energy Customer Segment is comprised of distribution companies, Itaipu and customers in rural areas. They can be grouped and differentiated among themselves because everyone is interested in the technological advance in the electric energy sector and the improvement in the quality of energy, but according to their needs. As for the value proposition, LASSE Smart Energy defined two important points to be dealt with customers: knowledge and dissemination of the concept, dealing with socio-environmental values, cost reduction, availability, and energy quality. One of the reasons for developing the Smart Grid was to help people located in hard-to-reach areas away from large centers such as rural areas. So, the first consumers of DG and MG of Paraná were the population of rural areas, that worked in the sector of agribusiness, like poultry farming. The production process requires the constant supply of electric energy since it depends on the thermal control and the lighting of the environment. A small event of lack of energy impacts the death of birds due to thermal stress, compromising the entire investment of the producer. For Itaipu, the value proposition would be made because of its interest in regional development, and could then. to use Smart Grid technology for this. The value proposition for distribution companies would be to increase the quality of electric power for rural areas, saving on expenditures on generation units and transmission lines. For communication with these customers, the channels defined by LASSE Smart Energy are R\&D notices, nominations, article publications and participation in events. In order to reach clients in rural areas of Paraná, the best way is by appointment, that is, people who have had experiences or know the work of LASSE indicate to others. For Itaipu and distribution companies, R\&D notices, the participation of events and the publication of articles are the best ways to contact them, due to the proximity that this event offers between the responsible of each company and the person in charge of LASSE Potential customers (people from rural areas, Itaipu and distribution companies) expect a kind of relationship that guarantees a good reason to opt for the LASSE business instead of the competition. Given this, LASSE Smart Energy establishes relationships through agreements and contracts allowing the negotiation of price and terms of business. In view of the value propositions that satisfy their needs, potential clients will be willing to pay for the micro-projects technical project, for the study to insert a new micronetwork and for specialized training. How much and how customers will pay for these offers may vary according to the complexity of the service.

Once the canvas value side has been completed, the efficiency side begins, describing the main features the company will seek to offer its value proposition. For this reason, one must know the Negotiation Tools and the Area Integration. Physical Resources are the equipment and software that make up the laboratory and requires the Intellectual Resources (technical skills) to operate them. The initial investment of the micro-project project may be by Technological Works (TW), the agreement and the FPTI. Finally, all previous resources are managed by Human Resources. In order to perform the services (Key Activities), value propositions require the electrical study and the viability of the micro-network, the channels and the relationship with the client depend on R\&D writing and technical material and, thus, the source of revenue will be the consequence of the TW in MG. The main partners and suppliers of LASSE Smart Energy continue to be those presented in section 3 since they are interested in developing and applying the micro-concept concept. Suppliers, for example, adapted their technology so that they could work on the key activities. Finally, from the other blocks, the Cost Structure are internal team qualification, equipment depreciation, material infrastructure and the costs of LASSE employees. According to the manager, all costs are important for the LASSE Smart Energy business model, the most expensive of which is the qualification of the team, since it requires them to have total control over the MG and this knowledge is acquired through technical, undergraduate, doctorate, participation of events, publications of articles; depreciation of equipment due to maintenance cost and human resources; the costs of the employees and the infrastructure of the laboratory.

The declaration of the function performed by the $\mathrm{MG}$ requires the knowledge of characteristics such as the possible products and services that can be commercialized, the markets where the marketing takes place and how this technology is used. In view of these interests and advantages, it is possible to define the role of the MG in the energy market (Fig. 3), considering the DG's own input and the financial investments of companies and organizations, and as a way of qualifying GD, the quality and availability of energy, cost reduction, socio-environmental values and R\&D.

By systematically analyzing LASSE, the declaration of its function for the MG demands the knowledge of the possible values that can be offered, if there are 
competencies for these values and if they coincide with the interests of the companies and organizations. Then, it defines as entry the own DG and the financial investments of the companies and organizations, and as output the value propositions of the LASSE. In the same way that LASSE seeks to participate in the DG market to increase its value capture, it is necessary to adapt its current characteristics so that it can offer value propositions, for example, training of internal staff, integration of electrical and automation and adaptation of the strategic process to this new way of capturing value.

In addition to internal interactions, the structure of the BM also depends on external interactions. In order to determine which companies or organizations LASSE has external interactions, it is enough to analyze interdependence. Therefore, it defines as external interactions the companies called LASSE partners. Within the partnerships, there are companies that, in the $\mathrm{MG}$ environment, carry out the same activities as LASSE as research institutions, and those that act as suppliers, such as the company that offers RTDS ${ }^{\circledR}$ technology. The declaration of the role of research institutions with LASSE requires the training of the skills to provide researchers. In this way, it defines as output the knowledge and expects, as a result, the development of researches. For suppliers, the declaration of the function of these companies for LASSE requires the supply of the technology (equipment) and expects payment as a return. Finally, the key to the $\mathrm{BM}$ is the interdependence between the company and the customer. In the application of Canvas identified with potential clients Itaipu, Rural Customers and distribution companies (COPEL). In order to determine the function of the clients in the MG for the LASSE, it associated the inputs and outputs of the MG to their needs. Thus, Itaipu's inputs are socioeconomic values, R\&D, GD qualification and power quality, and as an exit the financial investment. The inputs of Rural Customers are power availability, cost reduction, GDs qualification, and power quality, and as outputs the GD itself and the investment. Finally, the inputs of COPEL are R\&D, cost reduction and power quality.

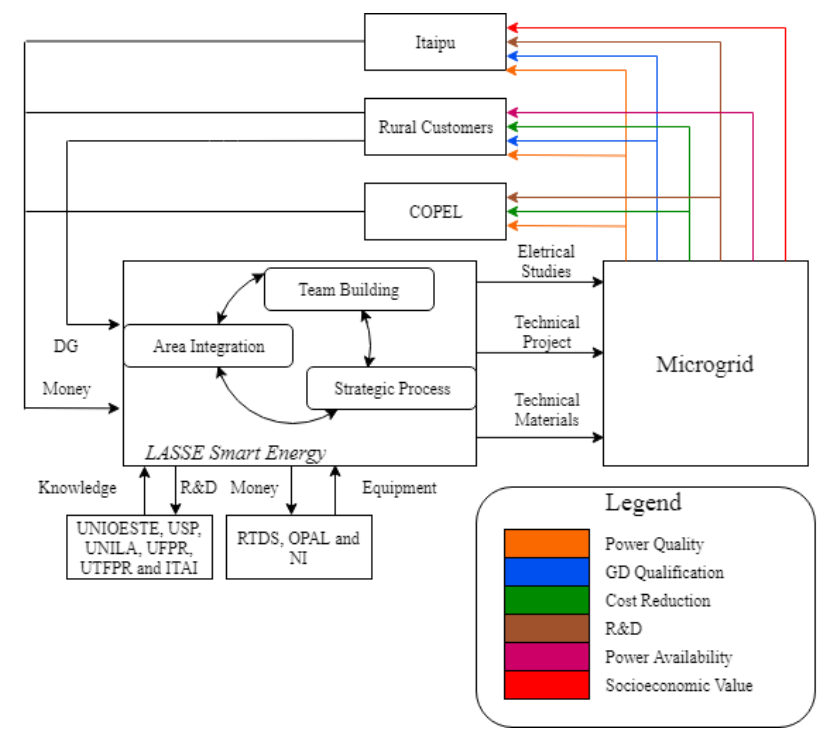

Fig 4. LASSE Smart Energy Systemic Map.

\section{Conclusion}

To participate in the MG market requires knowledge of the whole system, such as the environment, procedures, and stakeholders, in a concise, clear and conscious way. The MG is known for its complexity and dynamism. These characteristics require the LASSE technology updates and skills training constantly so that it knows how to position itself to obtain value from the environment. Thus, the contribution of this work to LASSE is in the guidelines that the systemic diagram provides and characterizes the nuances of the $\mathrm{MG}$ environment. Based on the information obtained through the variables of the company's systemic vision, the BM for the LASSE was developed in the MIG market through the use of the BMG methodology. The main activities were the description of the Smart Grid business model, the description of Lasse Smart Energy, the construction of the Canvas and the construction of the LASSE Smart Energy System Map. Thus, the work also contributes to companies that are interested in developing a business model for any branch, since the division with the body of work is possible to assist in the procedure of creating, capturing and delivering values to other BM.

\section{References}

[1] S. Chowdhury, S. P. Chowdhury, P. Crossley, Microgrids and Active Distribution Networks, The Institution of Engineering and Technology, London, United Kingdom (2009), pp; 2.

[2] T. Ackermann, G. Andersson, L. Soder, "Distributed generation: a definition", in Proc. Electric power systems research (2001), Vol. 67, pp. 195-204.

[3] R. H. Lasseter, "Smart Grid", in Proc. Power Engineering Society Winter Meeting, 2002. IEEE, Vol. 1, pp; 305-308.

[4] A, Abella et al, "Smart Energy: nuevas aplicaciones y modelos de negocio", in Proc. Cátedra de Energía de Orkestra y BCG, Vol. 1, pp.1-114.

[5] D. J. Teece, Business models, business strategy and innovation, Elsevier (2010), Vol. 43, pp. 172-194.

[6] A. Osterwalder, Y. Pigneur, C. L. Tucci, "Clarifying Business Models: origins, presente, and future of the concept", in Proc. Communications of AIS (2005), Vol. 15, pp 4.

[7] A. Osterwalder, Y. Pigneur, Business Model Generation: a handbook for visionaries, game changers, and challengers, John Wiley \& Sons (2010), Vol. 1, pp. 300.

[8] R. Antillón, "Como entendemos la Sistematización desde uma Concepción Metodológica Dialéctica? Documento para discusión”, in Proc. IMDEC-ALFORJA (1991), Guadalajara,

[9] B. Halecker, M. Hartmann, "Contribution of systems thing to business model research and business model innovation, in Proc. International Journal of Technology Intelligence and Planning (2013), Vol. 9, pp. 1403-1410.

[10]A. C. F. Caldana et al, "Negociação estratégica: uma Abordagem sistêmica das competências e dos Relacionamento envolvidos no processo, in Proc. Revista de Administração Contabilidade e Economia da Fundace, (2012), Vol. 3, pp. 650-655.

[11]D. M Han, J. H. Lim, “ Smart home energy management system using IEEE 802.15.4 and zigbee”, in Proc IEEE Transaction on Consumer Electronics (2010), Vol. 56, pp. 1403-1410. 